\title{
A Comparison of Bone Mineral Density Measurements in Two Different Regions of Turkey
}

\author{
Türkiye'nin iki Farklı Bölgesindeki Kemik Mineral Yoğunluğu \\ Ö/çümlerinin Karşılaştırılması
}

Ahmet Imerci, Nevres Hürriyet Aydoğan, Önder Yeniçeri*

Muğla Sıtkı Koçman University Faculty of Medicine, Department of Orthopaedics and Traumatology, Muğla, Turkey *Muğla Sıtkı Koçman University Faculty of Medicine, Department of Radiology, Muğla, Turkey

\section{Abstract}

Objective: It was aimed to compare the values of bone mineral density (BMD) measurements made of patients in the osteoporosis (OP) unit in the provinces of Muğla and Erzurum provinces and to determine OP prevelance.

Materials and Methods: The data were evaluated of a total of 3862 patients aged over 50 years, who were included in the study. Of patients; ages, sex, and body mass index (BMI) were recorded. Patients in Muğla were included in the $1^{\text {st }}$ group, and patients in Erzurum were included in the second group. The BMDs of the spine (L1-4) and hip (femur neck) in both groups were measured using the dual energy X-ray absorptiometry (DEXA) method.

Results: A total of 3862 patients were included in the study. In group 1, the total number of patients was 2611 and 2518 of them were female, 93 were male. In the group 2, 1251 patients were present and 1093 were female and 158 were male. The mean age was $63.63 \pm 8.84$ years in group 1 and $65.44 \pm 9.26$ years in group 2 , and the difference was statistically significant $(p<0.001)$. A statistically significant difference was determined between the groups in respect of BMI $(p<0.001)$. A statistically significant difference was determined between the femoral neck T-scores of the cases $(p<0.001)$. Between the females of the two groups, a statistically significant difference was determined in respect of the Lumbar 1-4 T-score but no difference was seen between the males ( $p<0.001, p=0.726$, respectively).

Conclusion: The femoral neck BMD values of patients in the Muğla region were found to be significantly lower than those of the patients in the Erzurum region. Despite the significant risk factors for BMD and OP in the Erzurum region of less sunlight and regional differences, the BMD values were determined to be higher. Nutritional habits are thought to be effective in the end. We believe that regional differences and local values are a factor to be considered in the interpretation of BMD.

Keywords: Bone mineral density, osteoporosis, treatment

\section{Öz}

Amaç: Muğla ve Erzurum illerinde osteoporoz (OP) ünitesinde kemik mineral yoğunluğu (KMY) ölçümü yapılmış hastaların değerlerini karşılaştırmak ve OP yaygınlığını belirlemek amaçlanmıştır.

Gereç ve Yöntem: Elli yaş üstü toplam 3862 hastanın verileri değerlendirilip ve çalışmaya dahil edildi. Hastaların; yaşları, cinsiyetleri ve vücut kitle indeksi (VKi) kaydedildi. Muğla'daki hastalar 1. gruba, Erzurum'daki hastalar ise 2. gruba dahil edilerek çalışma iki gruba ayrıldı. Her iki gruptaki omurga (L1-4) ve kalça (femur boyun) KMY'leri dual enerji X-ışını absorbsiyometri (DEXA) yöntemi kullanılarak ölçüldü.

Bulgular: Toplam 3862 hasta çalışmaya dahil edildi. Birinci grupta toplam hasta sayısı 2611 idi ve bunların 2518'i kadın, 93'ü erkekti. İkinci

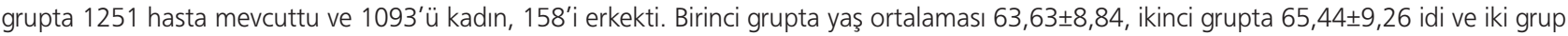
arasında anlamlı fark saptandı ( $<<0,001)$. VKi açısından iki grup arasında istatiksel olarak anlamlı fark saptandı ( $<<0,001)$. Olguların femur boyun T-skorları arasında anlamlı fark saptandı $(p<0,001)$. Lomber 1-4 T skoru her iki gruptaki kadınlarda anlamlı fark saptanırken, erkeklerde istatiksel olarak anlamlı fark saptanmadı (sırasılla; $p<0,001, p=0,726$ ).

Sonuç: Muğla bölgesinde femur boyun KMY değerleri Erzurum bölgesine göre anlamlı düşük bulunmuştur. Daha az güneşlenme süresi ve bölgesel farklılıklar düşük KMY ve OP için önemli risk faktörü olmasına rağmen Erzurum bölgesinde KMY değerleri daha yüksek bulunmuştur. Beslenme alışkanlıkları sonuçlarda etkili olduğu düşünülmektedir. Bölgesel farklılıların ve yerel değerlerin KMY yorumlanmasında göz önüne alınması gereken bir faktör olduğuna inanmaktayız.

Anahtar kelimeler: Kemik mineral yoğunluğu, osteoporoz, tedavi

Address for Correspondence/ Yazışma Adresi: Ahmet Imerci MD, Muğla Sıtkı Koçman University Faculty of Medicine, Department of Orthopaedics and Traumatology, Muğla, Turkey Phone: +90 5068935276 E-mail: ahmetimerci@hotmail.com ORCID ID: orcid.org/0000-0002-6474-8259 Received/Geliş Tarihi: 03.02.2017 Accepted/Kabul Tarihi: 12.10.2017 


\section{Introduction}

Osteoporosis (OP) is a systemic skeletal disease characterised by low bone mass and impaired bone micro-structure and thereby, increased bone fragility. In epidemiological studies the prevalence has been reported with regional differences observed as $40 \%-55 \%$ in females aged $50-60$ years, $75 \%$ in those aged $60-70$ years and as $85 \%-90 \%$ in those aged 70 years and over (1). OP varies according to geographical conditions. One of the factors determining this is vitamin $D$ (2). The synthesis of vitamin $D$ in the skin is affected by geographical location, seasons, age, weather, length of exposure to direct sunlight, race, skin colour, the use of suncream and manner of dress $(3,4)$.

Bone mineral density (BMD) measurement is used in the diagnosis of $\mathrm{OP}$, in the evaluation of fracture risk and in the follow-up of patients. Regardless of the measurement method used, low BMD is correlated to increased fracture risk $(3,5)$. When diagnosing OP, dual energy X-ray absorptiometry (DEXA) measurement is accepted as the gold standard (5). To evaluate the BMD values of the patients in this study and to be able to diagnose OP in the light of World Health Organization (WHO) criteria, BMD measurements are required in Turkey just as throughout the world.

To be able to correctly interpret BMD values, a comparison is necessary with reference values made from a large sample from different geographical areas according to age and gender with an examination of a population formed of healthy individuals, and therefore to obtain the correct figures of the frequency of $\mathrm{OP}$, it is important to reveal the real BMD reference values of the Turkish population and their related regional differences (6-9). BMD values are known to be affected by race, genetics, gender, age and environmental and regional differences $(6,7)$.

The aim of this study was to determine the prevalence of OP and to investigate whether or not regional characteristics were a risk factor by making a comparison of BMD values obtained with the DEXA method in two different provinces from two extreme regions of Turkey which are greatly different in respect of climate and geography, such as latitude, longitude and altitude, and in culture.

\section{Materials and Methods}

The study comprised a total of 3862 patients who had DEXA measurements taken between 2012 and 2014 at Muğla Sıtkı Koçman University Training and Research Hospital and Erzurum Palandöken State Hospital. Patients who have been living in Erzurum or Muğla for the last 5 years are included in this study. For each patient, a record was made of age, gender and body mass index (BMI). Approval for the study was granted by the Ethics Committee of Atatürk University (institutional review board number: 055/2013). Informed consent was obtained from all the study participants.

The patients were separated into two groups as patients in
Muğla as group 1 and patients in Erzurum as group 2. The BMD measurements of group 1 were taken with a DEXA Lunar-DPXIQ ${ }^{\circledR}$, and those of group 2 with a DEXA (Hologic Q 2000) unit. Measurements were taken of the posteroanterior lumbar spine (L1-L4) and the hip (femoral neck). The machine calibrations, tests, controls and phantom measurements were applied routinely by certified technicians. The participants removed outer clothing and were weighed and measured, then DEXA scanning was applied. The BMD values were evaluated with the T-scores defined acccording to the peak young adult bone density value. According to the WHO classification, patients with a T-score up to -1 standard deviation (SD) compared to the mean of same gender adults were evaluated as BMD value "normal", those with SD between -1 and -2.5 of the mean T-score of same gender adults were evaluated as "osteopenic" and those with SD below -2.5 compared to the mean T-score of same gender adults were evaluated as BMD "OP". The results of 1251 patients who underwent bone density screening with Hologic Q 2000 were converted to DEXA Lunar-DPX-IQ ${ }^{\circledR}$ results online with the standardization formula $(10,11)$.

\section{Statistical Analysis}

The study data were analysed using SPSS for Windows version 20 (SPSS Inc, Chicago, IL, USA) statistics software. Continuous variables were stated as mean \pm SD and categorical variables as percentage (\%). For comparison of the mean values the two sample z-test and the Student's t-test were used. A value of $p<0.05$ was accepted as statistically significant.

\section{Results}

A total of 3862 patients were included in the study. In group 1, there were 2611 patients comprising 2518 (96\%) females and 93 (4\%) males. In group 2, there were 1251 patients comprising 1093 (88\%) females and 158 (12\%) males. The mean age was $63.63 \pm 8.84$ years in group 1 and $65.44 \pm 9.26$ years in group 2 , and the difference was statistically significant $(p<0.001)$. A statistically significant difference was determined between the groups in respect of BMI $(p<0.001)$ (Table 1).

The BMD $\left(\mathrm{g} / \mathrm{cm}^{2}\right)$ of the femoral neck in the patients in group 1 was found to be statistically significantly lower than in group 2 in both genders $(p<0.001)$ (Table 2$)$. The lumbar 1-4 T-score of the females in group 1 was statistically significantly higher than that of group $2(p<0.001)$ but no difference was seen between the males $(p=0.726)$. In the group 2 patients from Erzurum there was no difference between the genders in the BMD values. In the group 1 patients from Muğla, the BMD values $\left(\mathrm{g} / \mathrm{cm}^{2}\right)$ of the males were determined to be lower than those of the females.

In group 1, 1281 (49\%) patients were evaluated as osteoporotic, 1125 (43\%) as ostepenic and 205 (8\%) as normal. In group 2, 511 (40.8\%) patients were classified as osteoporotic, 495 (39.5\%) as ostepenic and 245 (19.7\%) as normal. 


\begin{tabular}{|c|c|c|c|}
\hline Clinical characteristics & Muğla (n=2611) & Erzurum $(n=1251)$ & $p$ \\
\hline Female/male & $2518 / 93$ (96/4\%) & $1093 / 158(88 / 12 \%)$ & $<0.001$ \\
\hline Age (years) & $\begin{array}{l}\text { 63.63 } \pm 8.84 \\
\text { (min: } 50 \text { - max: 105) }\end{array}$ & $\begin{array}{l}65.44 \pm 9.26 \\
\text { (min: } 50-\max : 98)\end{array}$ & $<0.001$ \\
\hline Weight (kg) & $\begin{array}{l}71.79 \pm 14.42 \\
\text { (min: } 32 \text { - max: 147) }\end{array}$ & $\begin{array}{l}73.17 \pm 14.07 \\
\text { (min: } 33-\max : 130)\end{array}$ & 0.005 \\
\hline Height $(\mathrm{cm})$ & $\begin{array}{l}154.35 \pm 6.46 \\
\text { (min.: } 125-\max : 185)\end{array}$ & $\begin{array}{l}\text { 159.15 } \pm 7.67 \\
\text { (min: } 140-\max : 190)\end{array}$ & $<0.001$ \\
\hline BMI $\left(\mathrm{kg} / \mathrm{m}^{2}\right)$ & $\begin{array}{l}30.09 \pm 5.64 \\
\text { (min: } 13.49-\max : 65.33 \text { ) }\end{array}$ & $\begin{array}{l}28.88 \pm 5.23 \\
\text { (min: } 15.70-\max : 48.27)\end{array}$ & $<0.001$ \\
\hline \multicolumn{4}{|l|}{ Femoral neck T-score } \\
\hline \multirow{2}{*}{$\begin{array}{l}\text { Female } \\
\text { Male }\end{array}$} & $-2.26 \pm 1.08$ & $-1.47 \pm 1.01$ & $<0.001$ \\
\hline & $-2.83 \pm 1.19$ & $-1.47 \pm 1.19$ & $<0.001$ \\
\hline \multicolumn{4}{|l|}{ Lumbar 1-4 T-score } \\
\hline \multirow{2}{*}{$\begin{array}{l}\text { Female } \\
\text { Male }\end{array}$} & $-1.69 \pm 0.93$ & $-2.23 \pm 1.18$ & $<0.001$ \\
\hline & $-1.64 \pm 1.02$ & $-1.68 \pm 1.07$ & 0.726 \\
\hline Normal & $205(8 \%)$ & $245(19.7 \%)$ & \\
\hline Osteopenic & $1125(43 \%)$ & 495 (39.5\%) & \\
\hline Osteoporotic & $1281(49 \%)$ & $511(40.8 \%)$ & \\
\hline
\end{tabular}

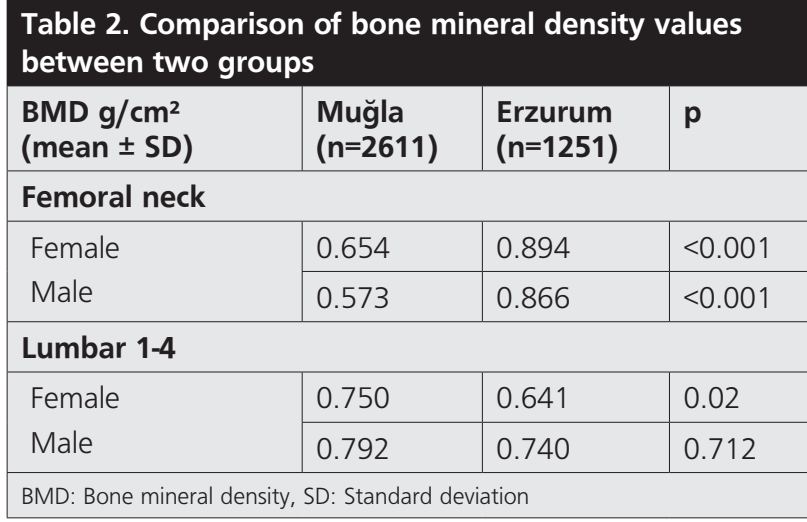

\section{Discussion}

While there was significant difference between the genders which could have affected the results of the two groups in the study, a significant difference was determined between the mean age and BMD values. Nearly all the DEXA units used in Turkey are used with the data of the USA and Europe as healthy population reference values, and studies and data accumulation oriented to normal population reference values are limited. For a good evaluation, it is mandatory to make a comparison with appropriate gender and race references (12).

In the KASTURKOS study by Aslan et al. (6), it was shown that the BMD values of Turkish females living in Kastamonu were lower than those of females living in other regions and thus OP was more widespread. Due to the geographical location of Turkey, the possibility of benefitting from sunlight is extremely high in three seasons according to meteorological data. Although Muğla is close to the coast with a greater exposure to sunlight and there is a great difference in altitude (approximately $2000 \mathrm{~m}$ ) from Erzurum, the femoral neck BMD values of the patients in Muğla were found to be lower. This demonstrates that there may not be sufficient benefit from many years of exposure to sunlight and that the regional style of dressing is a risk factor for low BMD. There may also be the awareness of the development of skin diseases in the avoidance of sunlight or the use of high factor protective products $(2,13)$. Some of those who are working outside all day may only have sunlight contact with the face and back of the hands because of the style of dressing. Genetics, anthropometrics, menopause age and nutrition may also be parameters affecting the results. Factors such as age, lifestyle, style of clothing, latitude, seasons and environmental factors affect the amount and duration of sufficient vitamin $\mathrm{D}$ synthesis that can be obtained by the body benefitting from sunlight (14-17). Stalgis-Bilinski et al. (18) researched the time, manner and duration of sunlight exposure necessary for sufficient vitamin D synthesis for healthy bones and it was suggested that half an hour in the morning before 10.00 and again after 15.00 with $11 \%-17 \%$ of the body exposed (hands and face) was sufficient. Despite climate differences, the OP rate in Muğla was greater. In a study related to the importance of the style of dressing, the relationship with $25(\mathrm{OH}) \mathrm{D}$ vitamin was examined and a direct relationship was determined between a style of dressing preventing sunlight contact with the skin and low serum levels of 25(OH)D (19). Pongchaiyakul et al. (14) investigated OP risk factors in 129 individuals aged 50-84 years and reported that reduced energy consumption and exposure to sunlight were serious risk factors for OP. 
Nutrition plays an important role in the pathogenesis, prevention and treatment of OP. Nutrition rich in calcium, potassium, magnesium, phosphorus, vitamin D and protein during childhood and the growth period is of great importance in reaching peak bone mass. Calcium and vitamin D have been shown to protect the bone mass in the elderly and reduce the risk of fractures (14). The regional nutritional habits could have had an effect on the results of the current study.

In the FRACTURK study, the femoral neck OP frequency was determined as $12.9 \%$ in Turkish females aged 50 years and over (20). Using their own reference values, Tunç et al. (21) determined femur total OP frequency as $10.8 \%$. Gölge et al. (22) compared BMD values in two different provinces and reported the OP frequencies as $13.7 \%$ and $52 \%$. Gemalmaz et al. (23) determined OP frequency as $10.8 \%$ in a study in Aydın, western Turkey. Many studies have been conducted on the frequency of OP in various countries and the lifetime risk of OP of females aged over 50 years has been reported as $30.3 \%$ in the USA, $40.8 \%$ in Denmark, $35.4 \%$ in Japan and $24.9 \%$ in Switzerland (24-27). In studies made on healthy individuals, the prevalence of OP in females in Saudi Arabia (28) and China (29) was calculated as $30.5 \%$ and $32.1 \%$ repectively. In Tunisian females, the OP prevalence in the femoral neck has been evaluated as $17.3 \%$ (30) while this rate was found to be $16.3 \%$ in Chinese females (29). In females in Canada, the prevalence of OP in the vertebral region (12.1\%) and the femoral neck (7.9\%) has been found to be much lower (31). In the current study, the OP prevalence in the two geographical regions was determined as $49 \%$ and $40.8 \%$ repectively (32). The reason for this could be attributed to the higher mean age of the patients in the study and in addition to genetic differences, a diet poor in calcium in the growth period and a lack of regular physical activity in childhood, adolescence and at older ages.

\section{Study Limitations}

The limitations of this study can be considered to be that the same make of DEXA unit was not used and that vitamin D levels were not examined. The significant difference between age and BMI values may also have affected the results. Prejudiced selection may have occurred due to differences in dietary habits and lifestyle of the majority. Secondly, It is weak to evaluate secondary factors such as diabetes, family story, smoking, menopause, rheumatoid arthritis, which may affect the result of BMD. Thirdly, It is a limitation not to investigate spondyloarthritis in the lomber region.

\section{Conclusion}

Regional differences and local values can be considered factors necessary to take into consideration in the interpretation of BMD values. However, as OP was determined in approximately half of the patients, it can be concluded that this disease is a major health problem in Turkey. There is a need for further multi-centre studies to update the data on the subject of OP in Turkey and to establish an accurate database.

\section{Ethics}

Ethics Committee Approval: Approval for the study was granted by the Ethics Committee of Atatürk University (institutional review board number: 055/2013).

Informed Consent: It was taken.

Peer-review: Externally and internally peer-reviewed.

\section{Authorship Contributions}

Surgical and Medical Practices: A.I.., Concept: A.I., Design: A.I., N.H.A., Data Collection or Processing: A.I., Ö.Y., Analysis or Interpretation: A.I., N.H.A., Literature Search: A.I., Ö.Y., Writing: A.I.

Conflict of Interest: No conflict of interest was declared by the authors.

Financial Disclosure: The authors declared that this study received no financial support.

\section{References}

1. Walker-Bone K, Dennison E, Cooper C. Epidemiology of osteoporosis. Rheum Dis Clin North Am 2001;27:1-18.

2. Sarıdoğan $M$, Akarırmak Ü, Eskiyurt N, Tüzün Ş. Türkiye'nin 3 farklı coğrafi bölgesindeki postmenopozal kadınlarda D vitamini ve kemik mineral yoğunluğunun korelasyonu. Turk J Osteoporos 2010;16:49-52.

3. Arunabh S, Pollack S, Yeh J, Aloia JF. Body fat content and 25-hydroxyvitamin D levels in healthy women. J Clin Endocrinol Metab 2003;88:157-61.

4. Brustad M, Alsaker E, Engelsen O, Aksnes L, Lund E. Vitamin D status of middle-aged women at 65-71 degrees $N$ in relation to dietary intake and exposure to ultraviolet radiation. Public Health Nutr 2003;7:327-35.

5. WHO. Assesment of osteoporotic fracture risk and its role in screening for postmenopausal osteoporosis. WHO Tecnical Report Series, Geneva; 1994.

6. Aslan A, Karakoyun O, Güler E, Aydin S, Gök MV, Akkurt S. Kastamonu'da yaşayan Türk kadınlarında kemik mineral yoğunluğu, osteoporoz yaygınlığı ve bölgesel risk faktörlerinin değerlendirilmesi: KASTÜRKOS çalışması. Eklem Hastalık Cerrahisi 2012;23:62-7

7. Pirimoğlu MZ, Alper $A G O ̈$, Büyükbayrak EE, Kars B, Afşin $Y$, Ünal $O$, et al. Body mass index seems the most effective factor on bone mineral density comparing postmenopausal time, age or reproductive factors in healthy postmenopausal women. Turkiye Klinikleri J Gynecol Obst 2011;21:1-5.

8. Baykara M. Bölgesel kadın popülasyonunda DEXA ile saptanan kemik mineral yoğunluğu değerlerinin Türk toplum standartlarılla karşılaştııılması. F.Ü. Sağlık Bil Dergisi 2005;19:231-9.

9. Dilşen G, Göksoy T, Barden HS, Selim N, İşsever H. Sağlıklı Türk toplumunda kemik mineral yoğunluğu değerleri. Aktüel Tıp Dergisi 2001;6:96-108.

10. Genant HK, Grampp S, Glüer CC, Faulkner KG, Jergas M, Engelke $K$, et al. Universal standardization for dual $\mathrm{x}$-ray absorptiometry: patient and phantom cross-calibration results. J Bone Miner Res 1994;9:1503-14.

11. Available from: http://www.measureup.com.au/convert-bmdmeasurements/ [Accessed; September 27, 2017].

12. Bozbaş GT, Gürer G. Dual Enerji X-Ray Absorpsiyometri Ölçümü ve Bu Sonuçları Etkileyen Faktörler. Türkiye Klinikleri J PM\&R-Special Topics 2009;2:76-83.

13. Matsuoka LY, Ide L, Wortsman J, MacLaughlin JA, Holick MF. Sunscreens suppress cutaneous vitamin D3 synthesis. J Clin Endocrinol Metab 1987;64:1165-8.

14. Pongchaiyakul C, Kosulwat V, Charoenkiatkul S, Chailurkit LO, Rojroongwasinkul N, Rajatanavin R. The association of dietary calcium, bone mineral density and biochemical bone turnover markers in rural Thai women. J Med Assoc Thai 2008;91:295-302. 
15. Atli T, Gullu S, Uysal AR, Erdogan G. The prevalence of Vitamin $D$ deficiency and effects of ultraviolet light on Vitamin $D$ levels in elderly Turkish population. Arch Gerontol Geriatr 2005;40:53-60.

16. Chapuy MC, Schott AM, Garnero P, Hans D, Delmas PD, Meunier PJ. Healthy elderly French women living at home have secondary hyperparathyroidism and high bone turnover in winter. EPIDOS Study Group. J Clin Endocrinol Metab 1996;81:1129-33.

17. Holick MF. Environmental factors that influence the cutaneous production of vitamin D. Am J Clin Nutr 1995;61(Suppl 3):638-45.

18. Stalgis-Bilinski KL, Boyages J, Salisbury EL, Dunstan CR, Henderson SI, Talbot PL. Burning daylight: balancing vitamin D requirements with sensible sun exposure. Med J Aust 2011;194:345-8.

19. Alagöl F, Shihadeh Y, Boztepe H, Tanakol R, Yarman S, Azizlerli $H$, et al. Sunlight exposure and vitamin D deficiency in Turkish women. J Endocrinol Invest 2000:23:173-7.

20. Tuzun S, Eskiyurt N, Akarirmak U, Saridogan M, Senocak M, Johansson $\mathrm{H}$, et al. Incidence of hip fracture and prevalence of osteoporosis in Turkey: the FRACTURK study. Osteoporos Int 2012;23:949-55

21. Tunç G, Doğan SC, Hizmetli S, Hayta E. Sivas ili Kentsel Bölgede Cumhuriyet Üniversitesi Hastanesi Fiziksel Tıp ve Rehabilitasyon Polikliniğine Başvuran Sağlıklı Kadınların Kemik Mineral Yoğunluğu Referans Değerlerinin Belirlenmesi. Turk J Osteopros 2014;20:104 9.

22. Gölge UH, Kömürcü E, Kaymaz B, Göksel F, Güzel Y, Adam G, ve ark. Türkiye'nin iki farklı bölgesindeki osteoporozun karşılaştırılması. Turk J Osteopros 2014;20:56-9.

23. Gemalmaz A, Dişcigil G, Soylemez A. Kentsel Bolgede Osteoporoz Taraması: Sıklık ve Illişkili Faktörler. Turkiye Klinikleri J Med Sci 2007;27:695-700

24. Melton LJ. How many women have osteoporosis now? J Bone Miner Res 1995;10:175-7.
25. Vestergaard P, Rejnmark L, Mosekilde L. Osteoporosis is markedly underdiagnosed: a nationwide study from Denmark. Osteoporos Int 2005;16:134-41.

26. Iki M, Kagamimori S, Kagawa $Y$, Matsuzaki T, Yoneshima $H$, Marumo F. Bone mineral density of the spine, hip and distal forearm in representative samples of the Japanese female population: Japanese Population-Based Osteoporosis (JPOS) Study. Osteoporos Int 2001;12:529-37.

27. Gauthier A, Kanis JA, Martin M, Compston J, Borgström F, Cooper $C$, et al. Development and validation of a disease model for postmenopausal osteoporosis. Osteoporos Int 2011;22:771-80.

28. Ardawi MS, Maimany AA, Bahksh TM, Nasrat HA, Milaat WA, Al-Raddadi RM. Bone mineral density of the spine and femur in healthy Saudis. Osteoporos Int 2005;16:43-55.

29. Wu XP, Liao EY, Zhang $H$, Dai $R C$, Shan PF, Cao XZ, et al. Determination of age-specific bone mineral density and comparison of diagnosis and prevalence of primary osteoporosis in Chinese women based on both Chinese and World Health Organization criteria. J Bone Miner Metab 2004;22:382-91.

30. Sahli H, Testouri N, Chihaoui MB, Salah AH, Cheour E, Meddeb N, et al. Bone mineral density in healthy Tunisian women. Maturitas 2009:20:227-32.

31. Tenenhouse A, Joseph L, Kreiger N, Poliquin S, Murray TM, Blondeau L, et al. Estimation of the prevalence of low bone density in Canadian women and men using a population-specific DXA reference standard: the Canadian Multicentre Osteoporosis Study (CaMos). Osteoporosis Int 2000;11:897-904.

32. İmerci A, Akgün U, Canbek U, Aydoğan NH, Kılınç CY, Yeniçeri Ö. Genel Ortopedi-Poster: 14 Türkiye'nin iki farklı bölgesindeki kemik mineral yoğunluğu ölçümlerinin karşılaştırılması. 25. Ulusal Türk Ortopedi ve Travmatoloji Kongresi. Acta Orthop Traumatol Turc 2015;49(Suppl):182. 